\title{
Modification of Media for Banana In Vitro Propagation with Foliar Fertilizer and Coconut Water in cv. Rajabulu
}

\author{
Siti Mardhikasari' ${ }^{1}$, Ahmad Yunus ${ }^{2}$ and Samanhudi ${ }^{2 *}$ \\ ${ }^{1}$ Department of Agronomy, Postgraduate Program, Universitas Sebelas Maret, Surakarta, Indonesia; \\ ${ }^{2}$ Department of Agrotechnology, Faculty of Agriculture, Universitas Sebelas Maret, Surakarta, Indonesia \\ *Corresponding author: samanhudi@staff.uns.ac.id
}

\begin{abstract}
The use of foliar fertilizers and coconut water is potential; foliar fertilizer is the alternative medium and coconut water is the plant growth regulator (PGR) in the banana tissue culture. This study aimed to examine the ability of foliar fertilizer to substitute Murashige and Skoog (MS) media and coconut water as the main source of cytokine. There are two factors in this research. The first factor is the media, which consist of three levels, i.e. fully MS, $1 / 2$ MS $+1 / 2$ foliar fertilizer and fully foliar fertilizer. The second factor is the coconut water with four levels of concentration i.e. 50, 100, 150 and $200 \mathrm{ml} \mathrm{l}^{-1}$. The results show that fully formulated foliar fertilizer had not been able to substitute or even compete with a fully MS media, but conversely foliar fertilizer was used to substitute $1 / 2$ MS media. This can be seen from the parameters of shoot length, leaf length, root number and root length with the highest yield that was found in MS media (8.7, 4.66, 3.33 and $3.23 \mathrm{~cm}$ ). The $50-100 \mathrm{ml} \mathrm{l}^{-1}$ concentrations of coconut water showed the best results by giving a significant effect on the number of roots and root length. The acclimatization of plantlets in this study was nearly $100 \%$, indicated by the formation of a complete organ.
\end{abstract}

Keywords: banana; coconut water; foliar fertilizer; in vitro; modification of media

Cite this as: Mardhikasari, S., Yunus, A., \& Samanhudi. (2020). Modification of Media for Banana In Vitro Propagation with Foliar Fertilizer and Coconut Water in cv. Rajabulu. Caraka Tani: Journal of Sustainable Agriculture, 35(1), 23-32. doi: http://dx.doi.org/10.20961/carakatani.v35i1.27756

\section{INTRODUCTION}

Banana is one of the horticultural products commodity from tropical and subtropical countries (Tripathi et al., 2015), which is already known by the world community and cultivated more or less in 120 countries (Dhanalakshmi and Stephan, 2014). Banana cultivation from prehistoric times of India showed a significant economic and social outcomes (Bairwa et al., 2015). Based on the commercial status, bananas occupied the fourth rank after rice, wheat and maize (Gebeyehu, 2013). In Indonesia, banana is the main fruit consumed by the community both in the form of fresh and manufactured products. Hence, need for bananas increases and it is commercially profitable. Consequently, the need must be in balance with effective cultivation for high yields.

Based on the morphological characteristics, bananas have a pseudo-stem growing from the corms below the surface of soil. A corm has a number of small corms, which have the potential to form suckers. The seedlings are traditionally used as seeds. The clump of Rajabulu banana grown in the field maximizes 4-5 tillers year ${ }^{-1}$. The seedling constraint from the saplings other than the size and age that are not same also potentially become a very competent inoculum source against disease transmission. In other words, to meet the targets of commercial expan-

\footnotetext{
* Received for publication February 9, 2019

Accepted after corrections October 9, 2019
} 
sion of banana crops, the availability of highquality uniform seeds is difficult to obtain. Propagation of bananas is usually conducted by using a banana sucker that grows around the parent plant. In addition, tissue culture techniques can be expected to solve the problem of procuring banana plant seedling (Eriansyah et al., 2018).

Conventional cultivation in bananas only produces five to ten seedlings in a year (Bairwa et al., 2015) and the results are still far from the expectation. The cultivation carried out on the field is prone to infectious diseases from mother to sucker and becomes the source of epidemics for pests that cause low productivity (Ngomuo et al., 2014). One of the cultivation techniques developed to increase banana productivity is the use of superior seedling. Communities generally use banana tillers for propagation, but obtaining healthy seedling is not easy because of inadequate availability. The main obstacle in the development of banana is the difficulty in obtaining high quality seedling. For this reason, breeding efforts need to be carried out to avoid extinction in nature.

Effective banana propagation with a large number of tillers that is disease free can be conducted with tissue culture technique (Elisama et al., 2013). Agarwal (2015) stated that tissue culture is a plant propagation method with environmental conditions and explants, which have been sterilized with chemical solutions, either in solid or in liquid media. The success of tissue culture technique is also determined by the growth hormone regulators to spur growth. Currently, the technique of plant propagation through in vitro culture has been widely applied to industrial food crops, one of which is the banana plant. Banana planters are highly fond of seedlings produced by tissue culture compared to seedling from tillers. It is because banana seedlings produced from tissue culture are fastergrowing and uniform, as well as can be provided in large quantities for a short time and are free of harmful pathogens (Avivi and Ikrarwati, 2004). Further, tissue culture technique is one of the models of sustainable farming systems, by applying appropriate technology as an effort to increase agricultural production (Mahmuddin, 2013), in this case, tissue culture acts as the production technique of superior seedling of plants.

Tissue culture technique has developed a lot of modifications of media and the use of growth hormone regulators, which incorporate both synthetic and natural hormones. Coconut water is one of the natural growth regulating hormones that contain phyto-hormone, especially cytokines and indole-3-acetic acid (IAA) (Muhammad et al., 2015) and gibberellin (Ge et al., 2007). Media used as the sites to grow must contain nutrients that are managed to meet the needs of plantlets. The use of foliar fertilizer as an alternative source of nutrients is found in Murashige and Skoog (Murashige and Skoog, 1962) media or known as MS media and thus it reduces the production costs (Abdalaziz et al., 2016). The application of foliar fertilizer on plants is very profitable (Tian et al., 2015); nutrients derived from the fertilizer leaves can be received directly by the plant tissue.

This research is aimed to find an alternative composition of MS substitution media with a foliar fertilizer and the best concentration of coconut water on the growth of banana cv. Rajabulu. Moreover, this research also examined the success rate of tissue culture processes to the acclimatization stage.

\section{MATERIALS AND METHOD}

\section{Experimental site}

This research was conducted at Tissue Culture Laboratory, Horticultural Seed Field (HSF) Salaman, Magelang, from April-October 2017.

\section{Planting materials}

Explant of banana Rajabulu seedlings was obtained from Horticultural Seed Field (HSF).

\section{Materials for planting media}

Materials for planting include MS media consisting of macronutrient $\left(\mathrm{KNO}_{3}, \mathrm{CaCl}_{2}\right.$, $\mathrm{NH}_{4} \mathrm{NO}_{3}, \mathrm{KH}_{2} \mathrm{PO}_{4}$ and $\mathrm{MgSO}_{4}$ ), micronutrient $\left(\mathrm{CuSO}_{4}, \mathrm{H}_{3} \mathrm{BO}_{3}, \mathrm{ZnSO}_{4}, \mathrm{Na}_{2} \mathrm{MoO}_{4}, \mathrm{KI}, \mathrm{CoCl}_{2}\right.$ and $\mathrm{MnSO}_{4}$ ); vitamins consisting of Myo-inositol, Pyridoxine $\mathrm{HCl}$, Thiamine $\mathrm{HCl}$ and Nicotinic acid; as well as $\mathrm{Na}_{2}$ EDTA and $\mathrm{FeSO}_{4}$ buffer solvents (Saad and Elshahed, 2012). This research also used coconut water as the alternative plant growth hormone. Coconut water contains cytokine hormone, $\mathrm{Ca}, \mathrm{Na}, \mathrm{Fe}, \mathrm{K}, \mathrm{P}$ and vitamin C. This research used young coconut due to relatively more cytokine and vitamin contents. Other media also used foliar fertilizer to substitute MS media.

\section{Explant sterilization method}

The seedlings of banana plants that selected for explant sources were cleaned by peeling the outer 
midrib until the remaining size was approximately $5 \mathrm{~cm}$ in height and $3 \mathrm{~cm}$ in diameter. The first sterilization was conducted outside the Laminar Air Flow Cabinet (LAFC). Explants were washed with detergent and scrubbed under flowing water till clean (Zinabu et al., 2018). Then, the explants were drained and immersed in a solution of fungicide and bactericide at a concentration of 2 $\mathrm{mg} \mathrm{l}^{-1}$ of water for eight hours. The second stage of sterilization was conducted in LAFC. The remaining explant midribs were removed as much as 1-2 midribs and then soaked in a $30 \%$ Clorox solution for 15 minutes. After that, the explants were washed thoroughly with distilled water. Midribs explants were removed 1-2 more and soaked again in a $15 \%$ Clorox solution for 10 minutes. Furthermore, the explants were peeled again, left only 3 midrib leaves and then dipped in 1\% Clorox solution. Explants were later planted in MS media previously added 2 ppm IAA (indole acetid acid) and 5 ppm BAP (benzyl amino purine).

\section{Explant preparation method}

The shoot explants that had developed were then split into two or four parts and transferred to new media to multiply the shoots. After explants multiplied with bud sizes of approximately $0.5-1$ $\mathrm{cm}$, they were transferred to the base media without plant growth regulator (PGR) (MS0) for three weeks to neutralize the explants from the influence of the previous PGR media.

\section{Experimental design}

The media used as the treatment were fully MS, $1 / 2$ MS + $1 / 2$ foliar fertilizer and fully foliar fertilizer, each of media was mixed with coconut water by concentration of 50,100, 150 and $200 \mathrm{ml}$ $1^{-1}$ so that there were 12 combinations of media treatment (P0K1, P0K2, P0K3, P0K4, P1K1, P1K2, P1K3, P1K4, P2K1, P2K2, P2K3, P2K4). The research was arranged in a Completely Randomized Design (CRD) with three replications.

The concentration for fully foliar fertilizer treatment was $3.0 \mathrm{~g} \mathrm{l}^{-1}$, the concentration for $1 / 2$ foliar fertilizer was $1.5 \mathrm{~g} \mathrm{l}^{-1}$, while the concentration for $1 / 2$ MS media was half of standard dose. Media were added with sugar as much as $30 \mathrm{~g}$ until the $\mathrm{pH}$ ranged between 5.8-6.2. After that, media were added with $8 \mathrm{~g}$ of agarose. Moreover, the media were sterilized in an autoclave for one hour with a pressure of 17.5 psi (Bidhari et al., 2018).

\section{Acclimatization}

Plantlet acclimatization in this study was carried out when the age of plantlets was 6 weeks. In some treatments, plantlet growth reached the maximum level in the bottle, while the nutrients provided by the media were perceived to be insufficient to support plant growth. The media used for acclimatization in this research were sand, goat manure and husk (Avivi et al., 2013) with a ratio of 1:1:0.5. Sand and husk used were sterilized by roasting them and then left about overnight. The mixture of the media was then sprayed with pesticides and inserted into a tub that had been plasticized and was then planted.

\section{Data analysis}

Data were analyzed using analysis of variance (ANOVA) by F test at 5\% level and if there was a significant difference, it was followed by a further test of Duncan's Multiple Range Test (DMRT) at $5 \%$ level (Akhiriana et al., 2019) using software of SPSS 16.0.

\section{RESULTS AND DISCUSSION}

\section{The length of shoot and leaf}

This research used three media types, namely fully MS media, $1 / 2 \mathrm{MS}+1 / 2$ foliar fertilizer and fully foliar fertilizer media. Table 1 showed that the media treatment was significantly different. MS media showed the highest shoot height of 8.71 $\mathrm{cm}$, followed by the media of $1 / 2 \mathrm{MS}+1 / 2$ foliar fertilizer and the lowest yield was at foliar fertilizer media. The insignificant results between fully MS media with $1 / 2 \mathrm{MS}+1 / 2$ foliar fertilizer indicate that the use of $1 / 2 \mathrm{MS}+1 / 2$ foliar fertilizer was almost comparable to the results of fully MS media used.

Sridhar and Aswath (2014) stated that the success of the culture process was determined by the composition of the media used. The media used in the regeneration of banana shoots (Table 1) show that MS media provided the highest yield by $8.71 \mathrm{~cm}$ and media of $1 / 2 \mathrm{MS}+1 / 2$ foliar fertilizer results were not significantly different compared to the MS media by $8.57 \mathrm{~cm}$, while foliar fertilizer media performed a very significant role in the two previous media types with the lowest yield of $5.48 \mathrm{~cm}$. The use of foliar fertilizer in this study could not show better results than MS media. Previous study (Ogero et al., 2012) shows similar results that the use of conventional media tends to be better at the variable of plantlet height compared to the use of 
foliar fertilizer media. The growth of shoots will be optimal under appropriate quantity of hormone and nutrition used, otherwise shoot growth will be inhibited and disturbed, especially if the quantity is scarce (Akhiriana et al., 2019).

Table 1. Effect of different media types on plantlet growth of banana at cv. Rajabulu after 8 weeks

\begin{tabular}{lcccc}
\hline \multicolumn{1}{c}{ Media type } & $\begin{array}{c}\text { Length of shoot } \\
(\mathrm{cm})\end{array}$ & $\begin{array}{c}\text { Length of leaf } \\
(\mathrm{cm})\end{array}$ & Number of root & $\begin{array}{c}\text { Length of root } \\
(\mathrm{cm})\end{array}$ \\
\hline MS & $8.71 \pm 1.264 \mathrm{~b}$ & $4.66 \pm 0.512 \mathrm{~b}$ & $3.33 \pm 1.981 \mathrm{~b}$ & $3.23 \pm 2.601 \mathrm{~b}$ \\
$1 / 2 \mathrm{MS}+1 / 2$ foliar fertilizer & $8.57 \pm 1.011 \mathrm{~b}$ & $4.23 \pm 0.481 \mathrm{~b}$ & $2.25 \pm 1.548 \mathrm{~b}$ & $3.16 \pm 2.440 \mathrm{~b}$ \\
Foliar fertilizer & $5.48 \pm 0.389 \mathrm{a}$ & $2.85 \pm 0.468 \mathrm{a}$ & $1.77 \pm 0.500 \mathrm{a}$ & $1.17 \pm 1.100 \mathrm{a}$ \\
\hline
\end{tabular}

Note: All the values are mean \pm SE, meaning that followed by different letter in the same column is significantly different by DMRT at $5 \%$ level

Based on DMRT analysis, type of media significantly affected the leaf length. Fully foliar fertilizer media gave different results compared to other media treatment with the lowest leaf length of $2.85 \mathrm{~cm}$. The MS medium had the highest mean of leaf length, $4.66 \mathrm{~cm}$ (Table 1). Leaf growth is a process of differentiation of leaf buds, with the addition of PGR such as auxin and cytokine which can encourage the differentiation process (Yuniastuti et al., 2018).

MS media in banana tissue culture, which are unmodified or called fully MS (Kahia et al., 2015), appeared to have the best results in the formation of banana plantlet organ including leaf length, root number and root length (Table 1). MS media substituted with half foliar fertilizer still show almost the same results. The result due to MS is a basic medium containing macro and micronutrient enriched with vitamins to supply plant growth nutrients (Saad and Elshahed, 2012). The research conducted by (Prabowo et al., 2018) shows that MS medium treatment presented the highest result on root number, root length and plant vigor variables. The best treatment found in the banana at cv. Mas Kirana shows the best results on the root number, root length, shoot length and plant vigor. Banana at cv. Mas Kirana (AA) is the same type as Rajabulu (AAB), but the genome is different which is commonly called the "banana table" (Valmayor et al., 2000).

The result of research indicates that the fully MS media and media contained with MS up to half could give almost the same results (Table 1). The highest root number of explants was found on MS media followed by $1 / 2$ MS $+1 / 2$ foliar fertilizer media with $3.33,2.25$ and $1.77 \mathrm{~cm}$ on full foliar fertilizer media. The longest roots were obtained in MS medium treatment followed by $1 / 2 \mathrm{MS}+1 / 2$ foliar fertilizer. The shortest result of roots was shown in fully foliar fertilizer treatment. The respective values for the treatment were $3.23,3.16$ and $1.17 \mathrm{~cm}$.

Foliar fertilizer media provided shorter leaf length compared with the length of MS media, 2.85-4.66 cm, the number of roots from 1.77-3.33 and the root length from $1.17-3.23 \mathrm{~cm}$. MS media substituted with alternative media did not always show good results, because they were not necessarily able to support sustainable growth (Sudarshana et al., 2012). Tafazoli et al. (2013) reported that MS media also gave the best result in callus induction of Castanea sativa Mill. MS is a medium that has been used in many of plant tissue culture and has much-known success. The composition of a medium is the main concern for the establishment of a successful plant cell and tissue culture technique (Manawadu et al., 2014).

\section{The number and length of root}

Plant tissue culture method is micropropagation technique that can be manipulated (Michael, 2011) from media and growth regulators used in accordance with the purpose. A previous research (Agampodi and Jayawardena, 2009) shows that coconut water contains growth hormone which normally can be used in tissue culture. Coconut water concentration puts effect on plantlet growth of banana at cv. Rajabulu after 8 weeks illustrated in Table 2. The length of roots formed on banana explants was observed right before acclimatization. Coconut water content (Table 3) could provide nutrients needed by plantlets to grow and develop during in vitro culture. Observations and measurements were made by measuring the longest root formed at the base of the explant.

The results of this study indicate that the concentration of coconut water at 50-100 $\mathrm{ml} \mathrm{l}^{-1}$ showed the best results on the number of roots and root length (Table 2). It means that the 
supplementation of culture media with coconut water can be beneficial for tissue growth and morphogenesis, not only of the mineral nutrients but also a natural growth regulator (Souza et al., 2013). Increasing the concentration of coconut water to $150 \mathrm{ml} \mathrm{l}^{-1}$ decreased the number of roots by 5.20 . It was also reported by (Gbadamosi and Sulaiman, 2012) that the addition of coconut water at a dose of $25 \%$ contributed to lower the root length of $1.67 \mathrm{~cm}$ into $1.00 \mathrm{~cm}$ on the propagation of Irvingia gabonensis.

Table 2. The effect of coconut water concentration on plantlet growth of banana at cv. Rajabulu after 8 weeks

\begin{tabular}{ccr}
\hline $\begin{array}{c}\text { Coconut water } \\
\left(\mathrm{ml} \mathrm{l}^{-1}\right)\end{array}$ & $\begin{array}{c}\text { Number of } \\
\text { root }\end{array}$ & $\begin{array}{c}\text { Length of root } \\
(\mathrm{cm})\end{array}$ \\
\hline 50 & $9.33 \pm 6.658 \mathrm{~b}$ & $11.60 \pm 8.914 \mathrm{~b}$ \\
100 & $9.00 \pm 5.567 \mathrm{~b}$ & $10.76 \pm 4.235 \mathrm{~b}$ \\
150 & $5.20 \pm 2.516 \mathrm{a}$ & $5.10 \pm 4.613 \mathrm{a}$ \\
200 & $2.36 \pm 2.200 \mathrm{a}$ & $3.33 \pm 2.916 \mathrm{a}$ \\
\hline
\end{tabular}

Note: All the values are mean \pm SE, meaning that followed by different letter in the same column is significantly different by DMRT at 5\% level

The same results were also shown in variables of root length, concentration of coconut water of 50-100 $\mathrm{ml} \mathrm{l}^{-1}$ which did not show any significant difference, as same as at concentrations of 150$200 \mathrm{ml} \mathrm{l}^{-1}$. However, there was the difference between these ranges, in which the concentration of coconut water reduced the length of root. Similarly, it was reported by other researchers (Shekarriz et al., 2014) that the addition of coconut water concentration decreased all morphology variables of culture. It was because the explant absorbed enough cytokines from coconut water at concentration of 50-100 $\mathrm{ml} \mathrm{l}^{-1}$. The higher concentration, on the contrary, can inhibit the growth of the explant. This in accordance with other study (Růžička et al., 2009) reporting that increased concentrations of exogenous cytokines can inhibit root growth and reduce root meristem size.

The use of cytokines on in vitro media depends on the growth stage and the desired final result (Hussein, 2012). The coconut water contains several organic compounds and mineral nutrients that are important for plant development (Souza et al., 2013). In addition, coconut water can also be used as an economical growth regulator element.

Coconut water contains $\mathrm{Ca} 4.67 \mathrm{mg}^{100 \mathrm{~g} \mathrm{~g}^{-1}, \mathrm{Na}}$ $41.06 \mathrm{mg} 100 \mathrm{~g}^{-1}$, Fe $0.68 \mathrm{mg} 100 \mathrm{~g}^{-1}, \mathrm{~K} 59.20 \mathrm{mg}$ $100 \mathrm{~g}^{-1}, \mathrm{P} 22.39 \mathrm{mg} 100 \mathrm{~g}^{-1}$, pH 3.54, total sugar $4.57 \%$ and vitamin C $4.87 \mathrm{mg} 100 \mathrm{~g}^{-1}$ (Andini, 2016). The concentration of coconut water used in this study shows significantly different results based on the analysis of variance. At the concentration of $50-100 \mathrm{ml} \mathrm{l}^{-1}$, the average number of roots was almost the same, 9.33-9.00. The average number of roots decreased when the concentration was 150-200 ml l-1, which produced 5.20 and 2.36 root numbers. In this study, the use of coconut water with a concentration of $50 \mathrm{ml} \mathrm{l}^{-1}$ gave the highest result on the average root length by $11.60 \mathrm{~cm}$, whereas if the concentration of coconut water was added up to the level of $200 \mathrm{ml}$ $\mathrm{I}^{-1}$, it decreased by $3.33 \mathrm{~cm}$. The formation of roots on fully MS media was better compared to the formation on media $1 / 2 \mathrm{MS}+1 / 2$ foliar fertilizer and full foliar fertilizer (Figure 1).
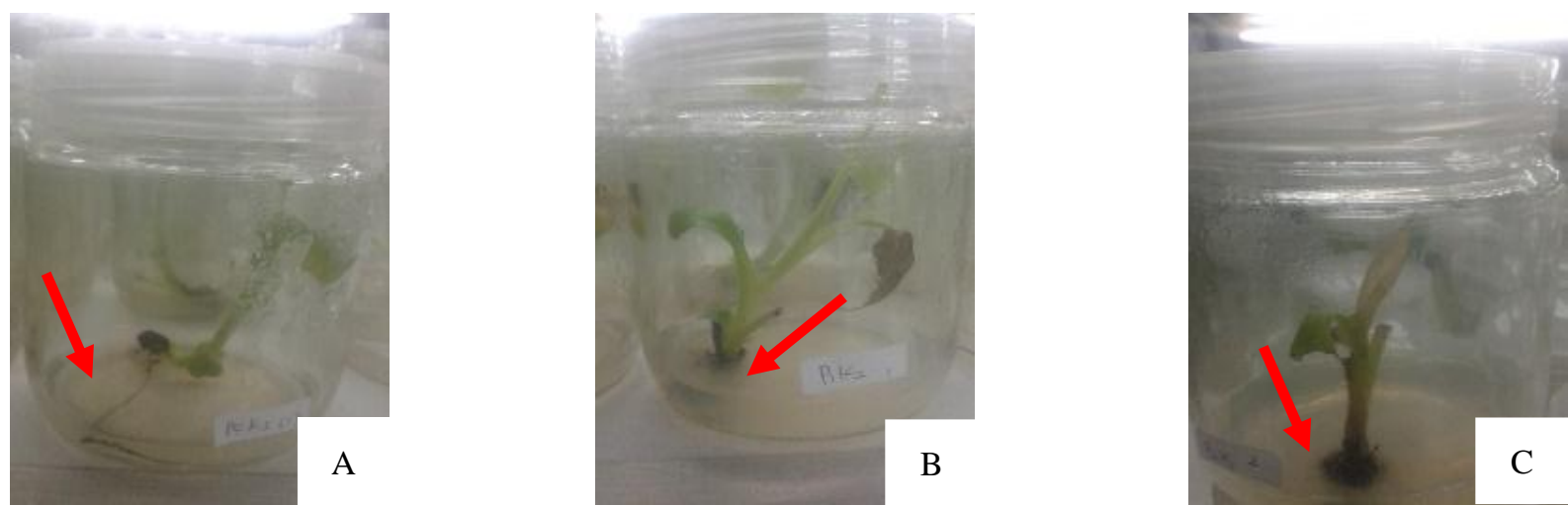

Figure 1. Banana plantlet at cv. Rajabulu on various types of media A (fully MS), B (1/2 MS $+1 / 2$ foliar fertilizer), C (Fully foliar fertilizer), each of which was combined with coconut water concentration of $100 \mathrm{ml} \mathrm{l}^{-1}$ 


\section{Regression of observed variables}

In this study, the effect of root growth variables was observed through the number of roots, meanwhile, other growth variables were observed using regression analysis. The regression line equation shows the relationship of the independent variable (x-axis) that is the number of roots, the dependent variable (y-axis) that is the height of shoots, number of shoots and number of leaves. The influence of the independent variable toward the dependent variable is shown in the value of the correlation coefficient (r). The regression equation presents a correlation among the number of roots, the root length, the shoot length and the leaf length.

The results of the regression equation presented in Figure 2 shows that the relationship between the number of roots and the length of roots had a positive correlation value. This indicates that root number is directly proportional to the root length, with a correlation coefficient of 0.615 and the average value of $61.5 \%$. It means that the root length of plantlet is influenced by the number of roots. It is in line with the results of the previous study on in vitro root regeneration of potatoes (Kumlay and Ercisli, 2015) that the root numbers of the plantlets were followed by the increase in root length. Root formation is a critical step. The success of the protocol also depends on the frequency of root formation (number of roots and root length) (Oumar et al., 2018).

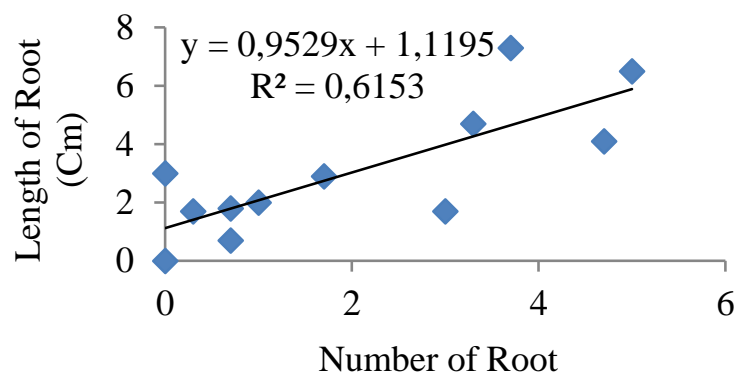

Figure 2. The regression between the number of root and the length of root

Figure 3 shows that regression analysis produced a positive correlation between the number of root and length of shots, with a correlation coefficient by 0.697 and the average value of $69.7 \%$. In this study, it can be concluded that based on regression results, the number of root variable was influenced by the length of the shoot (Mumo et al., 2013) in his research on Carica papaya $\mathrm{L}$ in vitro.

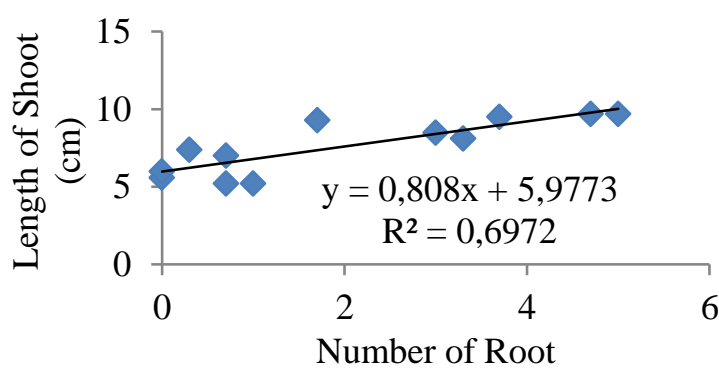

Figure 3. The regression between the number of root and the length of shoot

Each type of technology has disadvantages, including the process of propagating plants through in vitro. The most critical period in the in vitro process lies in the plantlet root formation and acclimatization (Gobena et al., 2018). Based on the regression analysis in this study, the number of roots had a positive correlation with the length of leaf of plantlets. Figure 4 demonstrates the correlation coefficient of 0.698 and the average value of $69.8 \%$, meaning that the correlation coefficient is high so that the growth of the number of roots affects the length of leaves. The same explanation was also stated by (Kozak and Sałata, 2011) in the in vitro multiplication of Rheum rhaponticum L, BA (benziladenin) hormone treatment on media to show an increase in leaf length as the number of roots increased. The probability of success on in vitro propagation depends on various factors including the type of media, $\mathrm{pH}$, lights, temperature and growth regulator (Samanhudi et al., 2018).

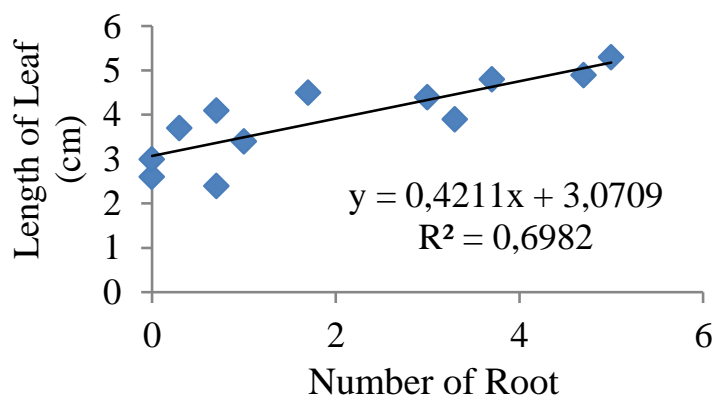

Figure 4. The regression between the number of root and the length of leaf 


\section{Acclimatization}

Plantlet in the bottle grew in the maximum level in some treatments, while the nutrients provided by the media were perceived to be insufficient to support plant growth. The acclimatization of banana plantlets resulted from tissue culture succeeded, except for foliar fertilizer media treatment combined with coconut water addition of $150-200 \mathrm{ml} \mathrm{l}^{-1}$. Based on Table 3 , fully MS media and $1 / 2 \mathrm{MS}+1 / 2$ foliar fertilizers treated with a coconut water concentration of 50$200 \mathrm{ml} \mathrm{l}^{-1}$ indicate that plantlets grew well until the second acclimatization. Acclimatization on banana plantlet was done gradually.

Table 3. The percentage of successful banana plantlet acclimatization in various treatments

\begin{tabular}{lcc}
\hline \multicolumn{1}{c}{ Treatments } & $\begin{array}{c}\text { Acclimatization } \\
\text { step 1 }(\%)\end{array}$ & $\begin{array}{c}\text { Acclimatization } \\
\text { step 2 }(\%)\end{array}$ \\
\hline MS + coconut water $50 \mathrm{ml} \mathrm{l}^{-1}$ & 100 & 100 \\
MS + coconut water $100 \mathrm{ml} \mathrm{l}^{-1}$ & 100 & 100 \\
MS + coconut water $150 \mathrm{ml} \mathrm{l}^{-1}$ & 100 & 100 \\
MS + coconut water $200 \mathrm{ml} \mathrm{l}^{-1}$ & 100 & 100 \\
$1 / 2 \mathrm{MS}+1 / 2$ foliar fertilizer + coconut water $50 \mathrm{ml} \mathrm{l}^{-1}$ & 100 & 100 \\
$1 / 2 \mathrm{MS}+1 / 2$ foliar fertilizer + coconut water $100 \mathrm{ml} \mathrm{l}^{-1}$ & 100 & 100 \\
$1 / 2 \mathrm{MS}+1 / 2$ foliar fertilizer + coconut water $150 \mathrm{ml} \mathrm{l}^{-1}$ & 100 & 100 \\
$1 / 2 \mathrm{MS}+1 / 2$ foliar fertilizer + coconut water $200 \mathrm{ml} \mathrm{l}^{-1}$ & 100 & 100 \\
Foliar fertilizer + coconut water $50 \mathrm{ml} \mathrm{l}^{-1}$ & 100 & 100 \\
Foliar fertilizer + coconut water $100 \mathrm{ml} \mathrm{l}^{-1}$ & 60 & 60 \\
Foliar fertilizer + coconut water $150 \mathrm{ml} \mathrm{l}^{-1}$ & 0 & 0 \\
\hline
\end{tabular}

Table 3 demonstrates that the acclimatization process was successful because the percentage reached $100 \%$, except for the treatment of foliar fertilizer media with coconut water concentration $150 \mathrm{ml} \mathrm{l}^{-1}$ and $200 \mathrm{ml} \mathrm{l}^{-1}$. It was because the plantlet did not have roots at the time of acclimatization, although acclimatization media had been given root stimulant nutrition of all the treatment. The plantlet was too small, and thus, it affected the success rate of acclimatization. The same result was expressed in the previous study of (Elisama et al., 2013) that in vitro explant conditions can be used as a critical determinant of acclimatization success in addition to environmental factors.

\section{CONCLUSIONS}

Based on the results of this research, MS medium substituted with foliar fertilizer up to half had the same result with the fully MS medium, and therefore, they can be used as the alternative media for in vitro banana propagation. The best concentration of coconut water used in this study was $50-100 \mathrm{ml} \mathrm{l}^{-1}$, however, the increase of concentration could decrease the results, especially on the variables of root number and root length. Plantlets acclimatization in this study was nearly $100 \%$ due to complete organs.

\section{ACKNOWLEDGMENT}

The authors are grateful to the Universitas Sebelas Maret for funding this research through the scheme of Penelitian Unggulan UNS (PU UNS) of PNBP UNS for fiscal year 2017.

\section{REFERENCES}

Abdalaziz, Z., Aboul-Nasr, M. H., Dokash, M. H., \& Metwaly, A. K. (2016). Using Stimufol ${ }^{\circledR}$ as an Alternative to MS Medium to Vrow Garlic in vitro. International Journal of Agriculture and Economic Development, 4(2), 21-28. Global Strategic Management Inc.

Agampodi, V. A., \& Jayawardena, B. (2009). Effect of coconut (Cocos nucifera L.) water extracts on adventitious root development in vegetative propagation of Dracaena purplecompacta L. Acta physiologiae plantarum, 31(2), 279-284. https://doi.org/10. 1007/s11738-008-0230-y

Agarwal, M. (2015). Tissue culture of Momordica charantia L.: A review. Journal of Plant Sciences Journal of Plant Sciences. Special Issue: Medicinal Plants, 3(1), 24-32. Retrieved from http://www.sciencepublishing group.com/journal/paperinfo.aspx? journalid= 215\&doi=10.11648/j.jps.s.2015030101.14 
Akhiriana, E., Samanhudi, \& Yunus, A. (2019). Coconut Water and IAA Effect on the In Vitro Growth of Tribulus Terrestris L. Acta Universitatis Agriculturae et Silviculturae Mendelianae Brunensis, 67(1), 9-18. https:// doi.org/10.11118/actaun201967010009

Andini, N. (2016). Penggunaan Air Kelapa dan Ekstrak Buah Pisang Terhadap Multiplikasi Tunas Temulawak (Curcuma xanthoriza Roxb.) Secara In Vitro (Thesis). Surakarta: Program Pascasarjana Universitas Sebelas Maret. Retrieved from https://digilib.uns.ac.id /dokumen/detail/54215/Penggunaan-Air-Kela pa-Dan-Ekstrak-Buah-Pisang-Terhadap-Multi plikasi-Tunas-Temulawak-Curcuma-Xanthor rhiza-Roxb-Secara-In-Vitro

Avivi, S., Hardjo Soedarmo, S., \& Andi Prasetyo, P. (2013). Multiplikasi Tunas dan Aklimatisasi Tiga Varietas Pisang: Raja Nangka, Kepok, dan Mas, Jurnal Hortikultura Indonesia, 4(2), 83-89. Retrieved from https://journal.ipb.ac.id /index.php/jhi/article/view/9548

Avivi, S., \& Ikrarwati. (2004). Mikropropagasi Pisang Abaca (Musa textillis Nee) Melalui Teknik Kultur Jaringan. Ilmu Pertanian, 10(2). 27-32. Retreived from http://i-lib.ugm.ac.id/ jurnal/detail.php?dataId $=5685$

Bairwa, K. C., Singh, A., Jhajaria, A., Singh, H., Goyam, B. K., Lata, M., \& Singh, N. (2015). Conventional sucker with tissue culture banana production in Central India-A case study. African Journal of Agricultural Research, 10(14), 1751-1755. https://doi.org/ 10.5897/AJAR2013.8382

Bidhari, L. A., Purwanto, E., \& Yunus, A. (2018). Effect of utilization of tomato extract and foliar fertilizer as media on shoots multiplication of banana cv Ambon in vitro. IOP Conference Series: Earth and Environmental Science, 142(1), 1-5. http:// doi.org/10.1088/1755-1315/142/1/012046

Dhanalakshmi, S., \& Stephan, R. (2014). Low cost media options for the production of banana (Musa paradisiaca L.) through plant tissue culture. Journal of Academia and Industrial Research (JAIR), 2(9), 509-512. Retrieved from http://www.jairjp.com/FEBR UARY\%202014/05\%20DHANALAKSHMI. pdf

Elisama, M.-L. M., Arturo, V.-V. V., Virginia, C.-
A., \& Luis, C.-S. (2013). Acclimatization of micropropagated Musa cavendischii cultivar roatan plants submitted to doses of fertigation and auxin. African Journal of Agricultural Research, 8(43), 5335-5340. Retrieved from https://www.researchgate.net/publication/260 210103_Acclimatization_of_micropropagated _Musa_cavendischii_cultivar_Roatan_plants submitted_to_doses_of_fertigation_and_auxi ns

Eriansyah, M., Susiyanti, S., \& Putra, Y. (2018). Pengaruh Pemotongan Eksplan dan Pemberian Beberapa Konsentrasi Air Kelapa terhadap Pertumbuhan dan Perkembangan Eksplan Pisang Ketan (Musa paradisiaca) Secara In Vitro. Agrologia, 3(1), 54-61. http://dx.doi. org/10.30598/a.v3i1.260

Gbadamosi, I. T., \& Sulaiman, M. O. (2012). The Influence of Growth Hormones and Cocos nucifera Water on the In Vitro Propagation of Irvingia gabonensis (Aubry-Lecomte ex O'Rorke) Baill. Nature and Science Nat Sci, 10(9), 53-58. Retrieved from http://freejournal.umm.ac.id/download-pdf-journal-708 5-the-influence-of-growth-hormones-and-coc os-nucifera-water-on-the-in-vitro-propagation -of-irvingia-gabonensis-aubrylecomte-ex-oror ke-baill.pdf

Ge, L., Peh, C. Y. C., Yong, J. W. H., Tan, S. N., Hua, L., \& Ong, E. S. (2007). Analyses of gibberellins by capillary electrophoresis-mass spectrometry combined with solid-phase extraction. Journal of chromatography A, 1159(1-2), 242-249. https://doi.org/10.1016/ j.chroma.2007.05.041

Gebeyehu, A. (2013). Effect of different combinations of 6-benzyl amino purine and naphthalene acetic acid on multiple shoot proliferation of plantain (Musa spp.) cv. Matoke from meristem derived explants. African Journal of Biotechnology, 12(7), 7180. Retrieved from https://www.ajol.info/ind ex.php/ajb/article/view/126706

Gobena, M., Hajare, S. T., \& Benti, G. (2018). In vitro Root Development System in Two Popular Cultivars of Banana. International Journal of Current Microbiology and Applied Sciences (IJCMAS), 7(1), 3583-3591. https:// doi.org/10.20546/ijcmas.2018.701.420

Hussein, N. (2012). Effects of nutrient media 
constituents on growth and development of banana (Musa spp.) shoot tips cultured in vitro. African Journal of Biotechnology, 11(37), 9001-9006. Retrieved from https://www. ajol.info/index.php/ajb/article/view/127352

Kahia, J., Ndaruhutse, F., Waweru, B., Bona venture, N., Mutaganda, A., Sallah, P. Y., Kariuki, N. P., et al. (2015). In vitro propagation of two elite cooking banana cultivars-FHIA 17 and INJAGI. International Journal of Biotechnology and Molecular Biology Research, 6(6), 40-47. https://doi. org/10.5897/IJBMBR2014.0231

Kozak, D., \& Sałata, A. (2011). Effect of cytokinins on in vitro multiplication of rhubarb (Rheum rhaponticum L.) 'Karpow Lipskiego' shoots and ex vitro acclimatization and growth. Acta Scientiarum Polonorum, Hortorum Cultus, 10(4), 75-87. Retrieved from http://hortorumcultus.actapol.net/pub/10 -4_75.pdf

Kumlay, A. M., \& Ercisli, S. (2015). Callus induction, shoot proliferation and root regeneration of potato (Solanum tuberosum L.) stem node and leaf explants under long-day conditions. Biotechnology and Biotech nological Equipment, 29(6), 1075-1084. http: //dx.doi.org/10.1080/13102818.2015.1077685

Mahmuddin. (2013). Paradigma Pembangunan Pertanian: Pertanian Berkelanjutan Berbasis Petani Dalam Perspektif Sosiologis. Jurnal Sosiologi Universitas Syiah Kuala, 3(1), 5976. Retrieved from http://jurnal.unsyiah.ac.id/ JSU/article/view/10599

Manawadu, I., Dahanayake, N., Gamini, S., \& Senanayake, N. (2014). Effects of Different Natural Organic Additives on in Vitro Shoot Regeneration of Raphanus sativus L. Var. Beeralu. Journal of Agricultural Science and Technology, 4, 219-223. Retrieved from https://www.researchgate.net/publication/309 133288_Effects_of_Different_Natural_Organ ic_Additives_on_in_Vitro_Shoot_Regenerati on_of_Raphanus_sativus_L_Var_Beeralu

Michael, P. S. (2011). Effects of coconut water on callus initiation and plant regeneration potentials of sweetpotato. Journal and Proceedings of the Royal Society of New South Wales, 144(3-4), 91-101. Retrieved from https://royalsoc.org.au/images/pdf/journal/144
_Michael.pdf

Muhammad, K., Gul, Z., Jamal, Z., Ahmed, M., Rehman, A., \& Khan, Z. U. (2015). Effect of coconut water from different fruit maturity stages, as natural substitute for synthetic PGR in in vitro potato micropropagation. International Journal of Biosciences (IJB), 6(2), 84-92. http://dx.doi.org/10.12692/ijb/6. 2.84-92

Mumo, N. N., Rimberia, F. K., Mamati, G. E., \& Wanjiku, A. (2013). In vitro regeneration of selected Kenyan papaya (Carica papaya L.) lines through shoot tip culture. African Journal of Biotechnology, 12(49), 6826-6832. Retrieved from https://www.ajol.info/index. php/ajb/article/view/130491

Murashige, T., \& Skoog, F. (1962). A revised medium for rapid growth and bio assays with tobacco tissue cultures. Physiologia plantarum, 15(3), 473-497. https://doi.org/ 10.1111/j.1399-3054.1962.tb08052.x

Ngomuo, M., Mneney, E., \& Ndakidemi, P. A. (2014). The in vitro propagation techniques for producing banana using shoot tip cultures. American Journal of Plant Sciences, 5(11), 1614-1622. https://doi.org/10.4236/ajps.2014 .511175

Ogero, K. O., Mburugu, G. N., Mwangi, M., Ngugi, M. M., \& Ombori, O. (2012). Low Cost Tissue Culture Technology in the Regeneration of Sweet Potato (Ipomoea batatas (L) Lam). Research Journal of Biology, 2(2), 51-58. Retrieved from https://www.researchgate.net/publication/303 460549_Low_Cost_Tissue_Culture_Technolo gy_in_the_Regeneration_of_Sweet_Potato_Ip omoea_batatas_L_Lam

Oumar, S., Modeste, K. K., Oi, K., Samuel, K., \& Edmond, K. K. (2018). Improved in vitro shoot proliferation and rooting of two banana varieties (FHIA-21 and PITA-3). European Journal of Biotechnology and Bioscience, 6(1), 24-29. Retrieved from http://www. biosciencejournals.com/download/441/5-6-27 -207.pdf

Prabowo, H., Yuniastuti, E., Samanhudi, \& Yunus, A. (2018). Effects of Media Combination With Concentration Of AB-Mix Nutrient On Growth Of Banana Shoots On In Vitro. Bulgarian Journal of Agricultural 
Science, 24(3), 404-410. Retrieved from http://www.agrojournal.org/24/03-08.html

Růžička, K., Šimášková, M., Duclercq, J., Petrášek, J., Zažímalová, E., Simon, S., Friml, J., Van Montagu, M. C. E., \& Benková, E. (2009). Cytokinin regulates root meristem activity via modulation of the polar auxin transport. Proceedings of the National Academy of Sciences, 106(11), 4284-4289. https://doi.org/10.1073/pnas.0900060106

Saad, A. I. M., \& Elshahed, A. M. (2012). Plant tissue culture media. Recent advances in plant in vitro culture. http://doi.org/10.5772/50569

Samanhudi, Yunus, A., Pujiasmanto, B., \& Saras, A. (2018). In Vitro Propagation of Temulawak (Curcuma xanthorrhiza Roxb.). Jurnal Jamu Indonesia, 2(2), 37-42. https://doi.org/10.29 244/jji.v2i2.30

Shekarriz, P., Kafi, M., Deilamy, S. D., \& Mirmasoumi, M. (2014). Coconut Water and Peptone Improve Seed Germination and Protocorm Like Body Formation of Hybrid Phalaenopsis. Agriculture Science Develop ments, 3(10), 317-322. Retrieved from https:// www.researchgate.net/publication/317674144 _Coconut_Water_and_Peptone_Improve_See d_Germination_and_Protocorm_Like_Body_ Formation_of_Hybrid_Phalaenopsis

Souza, R. A. V. de, Braga, F. T., Setotaw, T. A., Vieira Neto, J., Azevedo, P. H. de, Azevedo, V. H. de, \& Cançado, G. M. de A. (2013). Effect of coconut water on growth of olive embryos cultured in vitro. Ciência Rural, 43(2), 290-296. http://dx.doi.org/10.1590/S0 103-84782013000200016

Sridhar, T. M., \& Aswath, C. R. (2014). RETRACTED: Review on Medicinal Plants Propagation: A Comprehensive Study on Role of Natural Organic Extracts in Tissue Culture Medium. American Journal of Plant Sciences, 5(20), 3073-3088. http://dx.doi.org/10.4236/ ajps.2014.520324

Sudarshana, M. S., Niranjan, M. H., \& Rajashekar, N. (2012). Borassus pulp as substitute for sucrose and vitamins for in vitro cultures of some indian medicinal plants. International Journal of Pharma and Bio Sciences, 3(1), B414-B420. Retrieved from https://ijpbs.net/abstract.php?article=MTE2N $\mathrm{A}==$
Tafazoli, M., Nasr, S. M. H., Jalilvand, H., \& Bayat, D. (2013). Plant regeneration through indirect organogenesis of chestnut (Castanea sativa Mill.). African Journal of Biotech nology, 12(51), 7063-7069. Retrieved from https://www.ajol.info/index.php/ajb/article/vi ew/130547

Tian, S., Lu, L., Xie, R., Zhang, M., Jernstedt, J. A., Hou, D., Ramsier, C., et al. (2015). Supplemental macronutrients and microbial fermentation products improve the uptake and transport of foliar applied zinc in sunflower (Helianthus annuus L.) plants. Studies utilizing micro X-ray florescence. Frontiers in Plant Science, 5, 808. https://doi.org/10.3389/ fpls.2014.00808

Tripathi, J. N., Oduor, R. O., \& Tripathi, L. (2015). A High-Throughput Regeneration and Transformation Platform for Production of Genetically Modified Banana. Frontiers in Plant Science, 6, 1025. https://doi.org/10.3389 /fpls.2015.01025

Valmayor, R. V., Jamaluddin, S. H., Silayoi, B., Kusumo, S., Danh, L. D., Pascua, O. C., \& Espino, R. R. C. (2000). Banana cultivar names and synonyms in Southern Asia. International Network for the Improvement of Banana and Plantain (INIBAP) - Asia and the Pacific Office, Los Banos Laguna, Philippines. Retrieved from https://www.bioversityinterna tional.org/index.php?id=244\&tx_news_pi1\% 5Bnews $\% 5 \mathrm{D}=613 \&$ tx_news_pi $1 \% 5 \mathrm{~B}$ controll er\%5D=News\&tx_news_pi1\%5Baction\%5D $=$ detail $\& \mathrm{cHash}=\mathrm{cfce} 15 \mathrm{c} 3975 \mathrm{f} 71 \mathrm{fcb} 57610892$ $481 \mathrm{a} 581$

Yuniastuti, E., Widodo, C. E., Samanhudi, \& Delfianti, M. N. I. (2018). Effect of benzyl amino purine and indole-3-acetic acid on propagation of Sterculia foetida in vitro. IOP Conference Series: Earth and Environmental Science, 142(1), 012011. https://doi.org/10.10 88/1755-1315/142/1/012011

Zinabu, D., Gebre, E., \& Daksa, J. (2018). Explants Sterilization Protocol for In-vitro Propagation of Elite Enset (Ensete ventricosum (Welw.) Chessman) Cultivars. Asian Journal of Plant Science and Research, 8(4), 1-7. Retrieved from http://www.imed pub.com/articles/explants-sterilization-protoc ol-for-invitro-propagation-of-elite-enset-enset e-ventricosumwelw-chessman-cultivars.pdf 